\title{
GESTURE, MIMESIS AND IMAGE: ADORNO, BENJAMIN AND THE GUITAR MUSIC OF BRIAN FERNEYHOUGH
}

\author{
Diego Castro-Magas
}

\begin{abstract}
One important stimulus in attempting to apply Adorno's constellation of concepts on performance to Brian Ferneyhough's guitar music is that both display the influence of Walter Benjamin's thought. Benjamin's concept of mimesis influenced Adorno's theory of musical reproduction, however much Adorno may have reformulated it, and various Benjaminian topics are traceable in Ferneyhough's guitar music, especially Kurze Schatten II (1983-89) for solo guitar. Adorno claims that true reproduction is the X-ray image of the work of music, a rendition of all the aspects that lie hidden beneath the surface. By exploring the conceptual traces of Benjamin's thought in Kurze Schatten II, this article examines how performer's interpretative choices are likely to render the X-ray image of this music in performance, as seen through a gesture-based approach.
\end{abstract}

Most of Brian Ferneyhough's guitar music - namely Kurze Schatten II (1983-89) for solo guitar, Les Froissements d'Ailes de Gabriel (2003) for guitar and chamber ensemble, and the guitar duo No Time (at all) (2004) (which re-elaborates materials from Les Froissements) ${ }^{1}$-alludes in some way to Walter Benjamin. The title of the solo guitar piece is the same as Benjamin's sequence of aphoristic texts, while Les Froissements is the second act of Shadowtime (2004), Ferneyhough's 'thought opera' on Walter Benjamin. In this article, I will mainly discuss Kurze Schatten II, drawing upon my performances of the work and discussions with the composer. I also relate aspects of Theodor Adorno's theory of musical reproduction ${ }^{2}$ to recent scholarship on musical gesture and, most importantly, I propose some of Benjamin's texts as a potential source for an enriched understanding of both Adorno's Towards a Theory of Musical Reproduction and Ferneyhough's Kurze Schatten II.

\footnotetext{
${ }^{1}$ I exclude from this list Renvoi/Shards (2008) for quartertone guitar and quartertone vibraphone and other (non-soloistic) appearances of guitar and electric guitar in large ensemble pieces.

2 As expressed in Theodor W. Adorno, Towards a Theory of Musical Reproduction: Notes, a Draft and Two Schemata (Cambridge: Polity Press, 2006)
} 
Studies of performing issues in Ferneyhough's Kurze Schatten II include articles by guitarists from three different generations; ${ }^{3}$ however, only my own 2014 article seems to address the connection between the music and Benjamin's texts. ${ }^{4}$ Ferneyhough's own writings on the piece ${ }^{5}$ always refer to the last text of Benjamin's sequence Short Shadows (II), ${ }^{6}$ itself entitled 'Short Shadows'; it contains the image of the sun, casting shadows over objects while approaching its zenith until, at noon, every shadow disappears and 'everything becomes just itself, a quintessential monad'. This image, according to Ferneyhough, ${ }^{8}$ is captured in the re-tuning of strings progressively throughout the piece: beginning with an initial scordatura (which includes quartertones) one string is re-tuned after each pair of movements, to lead to the near-recovery (the second string remains tuned to $B$ ) ) of the guitar's standard sonority in the seventh and final movement. But I wonder about the remaining texts in Benjamin's sequence - is there any trace of them in the piece? Also, to what extent can an understanding of Benjamin's thought be useful for the interpretation of the music? Ferneyhough emphasises that his music is not programme music, but he acknowledges that most of his works engage some kind of extramusical ideas or starting-points: ${ }^{9}$ this leads one to presume that there could be always something hidden. In my view, it is this possibility that makes Adorno's idea of true reproduction as the X-ray image of the work - the rendition of all that lies hidden beneath the surface of sound - so amenable for this music.

In Towards a Theory of Musical Reproduction Adorno puts forward, within the dialectic between construction and expression, the image of musical writing as the graphic trace of the construction, 'the dialectical counterpart of the expression'. ${ }^{10}$ The image, in purely acoustic terms, always refers to the totality, and this pictorial character of musical writing (which does not refer merely to the visual representation of sound but to the spatialization of the flow of time) at once masks the gestural element. This gestural or 'mimetic' element, fundamental to expression in Adorno's theory, is referred to as the neumic aspect of notation. Adorno distinguishes three main elements in notation: the mensural, the neumic and the idiomatic. By mensural is understood all that is given unambiguously through symbols: 'mensural notation

\footnotetext{
3 Magnus Andersson, 'Brian Ferneyhough: Kurze Schatten II - considerations d'un interprète', Contrechamps 8 (1988), pp. 128-38; Geoffrey Morris, 'Brian Ferneyhough's Kurze Schatten II: Performance Approaches and Practices', Context 11 (1996), pp. 40-46; Diego Castro, 'Brian Ferneyhough's Kurze Schatten II: Towards an Auratic Model of Performance Practice', CeReNeM Journal 4 (2014), pp. 47-66.

4 Note, however, that this article concentrates on movements 1 and 2 only, and was written before I consulted the sketches/manuscripts for the piece and before I had been able to meet the composer.

5 Brian Ferneyhough, 'Kurze Schatten II for solo guitar', in Collected Writings, ed. James Boros and Richard Toop (London: Routledge, 1998), pp. 139-152; Brian Ferneyhough, 'Kurze Schatten II (1983-89)' [programme note], n.d., www.editionpeters.com/resources/0001/ stock/pdf/kurze_schatten_ii.pdf (accessed 4 February 2016).

${ }^{6}$ First published in 1933 in the Kölnische Zeitung and collected in Walter Benjamin, Selected Writings 1927-1934, Vol. 2, trans. Rodney Livingstone, ed. Michael W. Jennings, Howard Eiland and Gary Smith (Harvard: Belknap, 1999), pp. 699-702. The '(II)' appended to the title by the editors of the latter volume is used to distinguish this sequence - which contains seven texts - from the 1929 sequence of eight texts which Benjamin also titled Kurze Schatten (Short Shadows). The two sequences, although otherwise different, both conclude with the same text.

7 Ferneyhough, 'Kurze Schatten II for solo guitar', p. 139.

8 Ferneyhough, programme note.

9 Ferneyhough, 'Kurze Schatten II for solo guitar', p. 245.

10 Adorno, Towards a Theory of Musical Reproduction, p. 185.
} 
Example 1a:

Brian Ferneyhough's Kurze Schatten II, 1st movement, bars 1-2 as an expression of the duration of the notes'. ${ }^{11}$ As for the neumic, it 'is referred to as mimic, mimetic or gestural, the structural element to be interpolated from the symbols', ${ }^{12}$ referring to ancient neumic notation. ${ }^{13}$ The idiomatic is understood as 'the music-lingual element, i.e. that which must be reached through the musical language given in each case' ${ }^{14}$ That is, the element that contains a component of freedom in interpretation defining the personal style of the performer: 'in general the idea of speaking the instrument's language', which is in turn 'the legitimate place for the performer's subjectivity'. ${ }^{15}$ Thus, the relationship between these three elements leads towards one of the main theses in Towards a Theory of Musical Reproduction: that 'the task of musical interpretation is to transform the idiomatic into the neumic by means of the mensural'. ${ }^{16}$

Taking as an example the first two bars of Kurze Schatten II (Ex. 1a), my spaced re-notation makes this temporal spatialization more evident (Ex. 1b). The mensural element is all that is unambiguously given such as rhythm, dynamics (their relationship), and the composer's allocation of strings defining pitch. (Since in this score the tablature principle is employed, the scordatura strings are notated as if they were tuned normally.) The idiomatic element can be seen as the performer's trace in the realisation of these notated tasks. For instance, the micro-figure in the bottom stave in bar 2 requires the player to play the two notes on the fifth string in position IX, then to shift to position II (for the third string) while playing the open second string. This passage has been played (and recorded) very often with a small tenuto on the open $\mathrm{B} a$ (sounding $\mathrm{B} b$ ), because of the shift; however, this is not a neumic element.

(a)

Kurze Schatten II

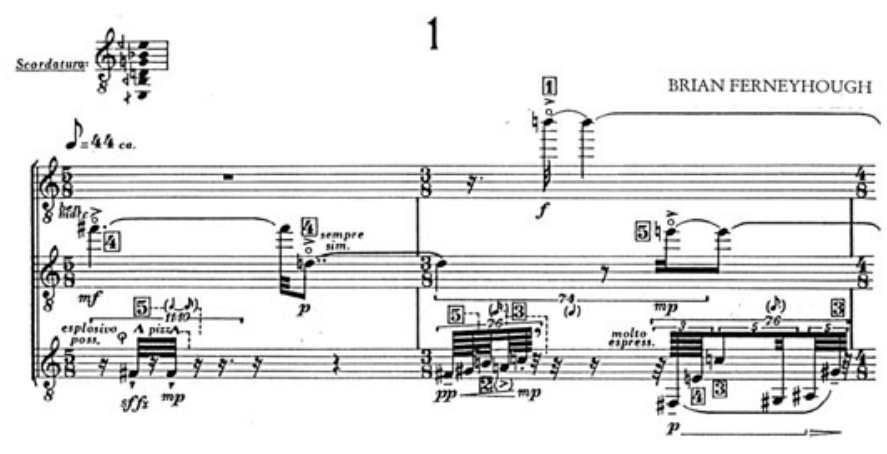

11 Adorno, Towards a Theory of Musical Reproduction, p. 62.

12 Adorno, Towards a Theory of Musical Reproduction, p. 67.

13 Neumic notation - itself of Greek origin - was developed from cheironomy: the imitation of 'the hand-movements of the choral conductor of antiquity, who directed the melodic movement and the corresponding movements of the choir. (Adorno, Towards a Theory of Musical Reproduction, draws here on Hugo Riemann, Handbuch der Musikgeschichte, Vol. I: Altertum und Mittelalter (bis 1300), 3rd edn, ed. Alfred Einstein (Leipzig, 1923).)

14 Adorno, Towards a Theory of Musical Reproduction, p. 62.

15 Adorno, Towards a Theory of Musical Reproduction, p. 55.

16 Adorno, Towards a Theory of Musical Reproduction, p. 67. 
Example 1b:

Spaced re-notation of Brian Ferneyhough's Kurze Schatten II, 1st movement, bars 1-2. (b)

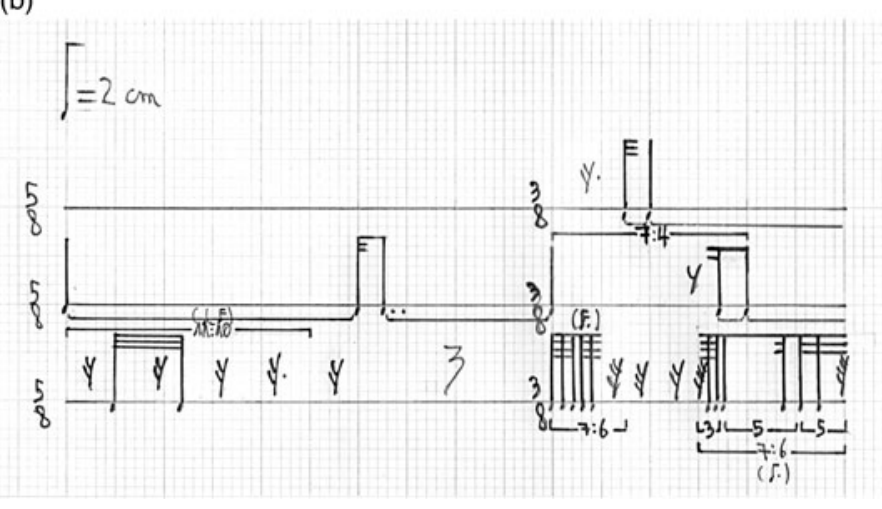

Adorno insists that the neumic element, however ambiguous, contains the otherwise repressed mimetic element: it invokes music in its immediacy, and the task of musical writing is the pursuance of a synthesis between unambiguity and immediacy, which persists to this day as a fundamental problem. Thus, Adorno's X-ray image of the work of music - 'all aspects of context, contrast and construction that lie hidden beneath the surface of the perceptible sound ${ }^{17}$ - contains the neumic element, as a dialectical counterpart to the image.

Adorno's concept of mimesis, which is central to the X-ray image, can be traced in Benjamin's essays 'Doctrine of the Similar' and 'On the Mimetic Faculty', both written in $1933 .{ }^{18}$ Benjamin argues that the very greatest capacity for the generation of similarities belongs to human beings, which is codetermined by their mimetic faculty, supposed to be stronger in primitive people: 'Our gift for seeing similarity is nothing but a weak rudiment of the once powerful compulsion to become similar and also to behave mimetically.. ${ }^{19}$ Language, Benjamin insists, may be seen as the highest level of mimetic behaviour and the most complete archive of similarities, of which he distinguishes two types: sensuous similarity and non-sensuous similarity. Benjamin regards these two as the components of reading:

The schoolboy reads his $\mathrm{ABC}$ book, and the astrologer reads the future in the stars. In the first clause, reading is not separated out into its two components. Quite the opposite in the second, though, which clarifies the process at both its levels: the astrologer reads the constellation from the stars in the sky: simultaneously, he reads the future or fate from it. ${ }^{20}$

The mimetic element in language, according to Benjamin, can manifest itself only through the semiotic element. Adorno puts forward these two aspects of language - the mimetic and the semiotic with regard to performance as implicit in the word 'Darstellung', which means both presentation and representation. Adorno often uses the word when referring to the act and practice of performance, where a piece is presented to the public; but he also brings out, according to Wieland Hoban, the implicit representation of musical meaning in the act of presentation: 'it thus implies both the mimetic

\footnotetext{
17 Adorno, Towards a Theory of Musical Reproduction, p. 1.

18 Collected in Benjamin, Selected Writings.

19 Benjamin, Selected Writings, p. 698.

${ }^{20}$ Benjamin, Selected Writings, p. 697.
} 
(an imitation and reproduction of the work) and the semiotic (the realisation and transmission of music-immanent meaning)'. ${ }^{21}$

It could be argued that the approach to the mimetic element from a performer's perspective manifests in the realm of gesture. ${ }^{22}$ Defined by Robert Hatten as 'any energetic shaping through time that may be interpreted as significant', ${ }^{23}$ gesture is a term which has the advantage of bypassing the Cartesian divide between body and mind ${ }^{24}$ (as well as fluctuating, it could be argued, between construction and mimesis). Within this fluctuation, my claim is that notation, as the model for imitation that Adorno advocates, requires the performer to embrace the two components of reading that Benjamin distinguishes as sensuous and non-sensuous similarity. That is, if sensuous similarity can be seen as the imitation of musical symbols, non-sensuous similarity can be regarded as the imitation of an (extramusical) idea.

To consider Example 1 again, there are various aspects that a correct rendition of the mensural aspects of notation still leaves ambiguous, and whose disambiguation defines the neumic element - such as tone-colour, or what to do in the junctures between micro-figures at the bottom stave. As a parallel, Benjamin's first text in Short Shadows (II), 'Secret Signs', addresses the concept of epiphany: ${ }^{25}$ 'what is decisive is not the progression from one piece of knowledge to the other but the leap implicit in any one piece of knowledge'. ${ }^{26}$ My personal response to this thought-image, in correspondence with the rendition of the score, is to do as much as possible to differentiate the molto espressivo figure at the end of bar 2: a sul tasto tone-colour plus vibrato on the long $\mathrm{C}$, while playing the remaining materials sul ponticello and non-vibrato. In addition, shifting is differentiated too: shifts are placed always at the very last moment, avoiding 'reverberation' - that is, body motion that continues in the juncture between phrases. ${ }^{27}$ These decisions are applicable to the rest of the movement as there are always some espressivo micro-figures, ${ }^{28}$ which I interpret as 'epiphanies' in the context of the piece. This set of decisions is what I understand then as the neumic element, here derived from a (non-sensuous) similarity with Benjamin's text.

${ }^{21}$ Hoban in Adorno, Towards a Theory of Musical Reproduction, p. xix. Hoban is both the translator of Towards a Theory of Musical Reproduction and also a remarkable composer.

${ }^{22}$ See Rolf Inge Godøy and Mark Leman, eds, Musical Gestures: Sound, Movement and Meaning (New York: Routledge, 2010).

${ }^{23}$ Robert S. Hatten, Interpreting Musical Gestures, Topics, and Tropes: Mozart, Beethoven, Schubert (Bloomington: Indiana University Press, 2004), p. 95. Meanwhile, François Delalande claims gesture to be the intersection of observable actions and mental images ('La gestique de Gould: élements pour une sémiologie du geste musical', in Glenn Gould Pluriel, ed. G. Guertin (Quebec: Louise Courteau), pp. 85-111), and Anthony Gritten and Elaine King state: 'A gesture is a movement or change in state that becomes marked as significant by an agent. This is to say that for movement or sound to be(come) gesture, it must be taken intentionally by an interpreter, who may or may not be involved in the actual sound production of a performance, in such a manner as to donate it with the trappings of human significance'. 'Introduction', in Music and Gesture, ed. Anthony Gritten and Elaine King (Aldershot: Ashgate, 2006), p. xx.

24 Alexander Refsum Jensenius, Marcelo M. Wanderley, Rolf Inge Godøy and Marc Leman, 'Musical Gestures: Concepts and Methods in Research', in Godøy and Leman, Musical Gestures, pp. 12-35 (here p. 13).

${ }^{25}$ Ferneyhough used this term when he and I discussed the text in an interview/rehearsal in 2013.

${ }^{26}$ Benjamin, Selected Writings, p. 699

27 Elaine King, 'Supporting Gestures: Breathing in Piano Performance', in Musical Gestures, p. 145.

28 Termed as 'melodies' in the composer's sketches at the Paul Sacher Foundation. 
The ties (or 'analogical bridges', to use Frank Cox's term) ${ }^{29}$ between similarity and performance can be made of gestures. Thus, the performer's body is always a parameter (whether notated or not), in light of the functionalities of musical gestures. The main functional categories of gestures have been defined as sound-producing gestures and sound-accompanying gestures ${ }^{30}$ - the former category means the body movements necessary for producing sound (including sound-facilitating gestures), whereas the latter corresponds to all body movements that may be made to music but not involved in sound production (including communicative gestures, also called 'semiotic gestures'). Consequently, a gesture-based approach means the attempt to transform sound-producing gestures into 'semiotic' gestures - at least within the performer's intention - as the result of an embodied mimesis of the work.

\section{Ferneyhough's Kurze Schatten II and its (X-ray) image}

On the assumption that Benjamin's influence on Ferneyhough's Kurze Schatten II is likely to inform the work's X-ray image, I checked the collection of manuscripts and sketches relating to this piece at the Paul Sacher Foundation in Basel. As seen there, a manuscript of the first movement dated 1983 reveals that the first projected title of the piece was Emblems - reaffirming the Benjamin connection. ${ }^{31}$ Also there is a manuscript of the first three movements, dated 1984, where I found the only proper Benjamin quotation in the sketches: 'Die Ideen verhalten sich zu den Dingen wie die Sternbilder zu den Sternen' (Ideas are to objects as constellations are to stars) - this quotation, as well as Benjamin's concern with emblems, relate to Ursprung der Deutschen Trauerspiels, on which I will comment in the final section of this article. At the same time, I embarked upon the task of reading Benjamin's text-sequence, looking for similarities between Ferneyhough's composition and Benjamin's texts. Short Shadows (II) may be regarded as belonging to the often neglected literary genre of Denkbilder (thought-images), ${ }^{32}$ Benjamin's reformulation of the Baroque emblem, ${ }^{33}$ which retains its tripartite structure of a lemma or title, an icon or image (verbally described in this case) and an epigram or conclusive thought. Moreover, Ferneyhough indicates that each piece in the cycle attempts, like an elaborate study, to concentrate its criteria of composition around a uniquely specific issue.

${ }^{29}$ Frank Cox, 'Notes toward a Performance Practice for Complex Music', In Polyphony and Complexity, ed. Claus-Steffen Mahnkopf, Frank Cox and Wolfram Schurig (Hofheim: Wolke-Verlag, 2002), pp. 70-132. Cox coins the term when advocating 'translation' in the communicative chain of conception, notation, realization and perception: 'Each domain in this chain should be seen as qualitatively different from the other: each has its own independent structuring, imperatives and history, and could be treated as a separate "language". Following this analogy, the translation between domains (as with human languages) must begin by acknowledging their fundamental differences, then attempt to create analogical bridges' (p. 104).

30 Rolf Inge Godøy, 'Gestural Affordances of Musical Sound', in Musical Gestures: Sound, Movement, and Meaning, pp. 103-25, here p. 110.

31 See also Ferneyhough, 'Kurze Schatten II for solo guitar', p. 246.

32 See Gerhard Richter, Thought-Images (Stanford: Stanford University Press, 2007). According to Richter, the Denkbild 'is a poetic mode of writing, a brief snapshot-in-prose that stages the interrelation of literary, philosophical, political, and cultural insights', mostly employed by four major German-Jewish philosophers associated with what came to be known as the Frankfurt School of critical theory.

33 See Karoline Kirst, 'Walter Benjamin's Denkbild: Emblematic Historiography of the Recent Past', Monatshefte 86/4 (Winter 1994), pp. 514-24. 
Example 2 summarizes the topics of both Benjamin's texts and Ferneyhough's pieces. ${ }^{34}$

Example 2:

Topics of each text/movement in Benjamin's Short Shadows (II) and Ferneyhough's Kurze Schatten II.

\begin{tabular}{|c|c|c|}
\hline & Benjamin & Ferneyhough \\
\hline I & $\begin{array}{l}\text { 'Secret Signs': deals with the concept of } \\
\text { epiphany through the image of ancient carpet } \\
\text { patterns. }\end{array}$ & $\begin{array}{l}\text { Concentrates on the problem of working with } \\
\text { two distinct types of polyphonic structures - one } \\
\text { made of two staves of natural harmonics, the } \\
\text { other made of four independent categories of } \\
\text { micro-figure that succeed each other with such } \\
\text { rapidity that occasional overlappings are } \\
\text { encountered. }\end{array}$ \\
\hline II & $\begin{array}{l}\text { 'A Saying of Casanova's': on the dialectical } \\
\text { function of money in prostitution, which buys } \\
\text { pleasure while at the same time becoming the } \\
\text { expression of shame (further developed in The } \\
\text { Arcades Project, convolute O, 'Prostitution and } \\
\text { Gambling'). }\end{array}$ & $\begin{array}{l}\text { The potential distinction between performance } \\
\text { tempo and density of material. In six panels of six } \\
\text { bars each, the tempo decreases while density } \\
\text { increases. }\end{array}$ \\
\hline III & $\begin{array}{l}\text { 'The Tree and Language': invokes the image of } \\
\text { a tree and explores ideas about language, } \\
\text { knowledge and names. }\end{array}$ & $\begin{array}{l}\text { The perception of time-flow and distribution in a } \\
\text { highly symmetrical scheme, in which a series of } \\
\text { bars alternate (long) bars of sound and (short) bars } \\
\text { of rest/silence in the first half, running in } \\
\text { retrograde in the second half which alternates } \\
\text { short bars of sonic events and long bars of silence } \\
\text { and tenuto. }\end{array}$ \\
\hline IV & $\begin{array}{l}\text { 'Gambling': evokes the passion of gamblers and } \\
\text { their 'cold blood' in the face of losses through an } \\
\text { image of a real gambler in Parisian clubs (further } \\
\text { developed in The Arcades Project, convolute O, } \\
\text { 'Prostitution and Gambling'). }\end{array}$ & $\begin{array}{l}\text { Waltz in ABA form, in which the left-hand agility } \\
\text { is seen as an independent variable in the context } \\
\text { of notated material that frequently goes against } \\
\text { what would be natural for the performer. }\end{array}$ \\
\hline V & $\begin{array}{l}\text { 'Distance and Images': explores the idea of } \\
\text { knowledge through images, ignoring the facts } \\
\text { happening at the distance beyond the image. }\end{array}$ & $\begin{array}{l}\text { A chordal proliferation principle aiming to } \\
\text { explore articulation and the great colouristic } \\
\text { potential of the instrument - a Charakterstück, in } \\
\text { Ferneyhough's terms. }\end{array}$ \\
\hline VI & $\begin{array}{l}\text { 'To live without leaving traces': a comment on } \\
\text { traceability and experience - further developed } \\
\text { in the essay 'Experience and Poverty' } \\
\text { (Benjamin, Selected Writings, pp. } 731-6 \text { ). }\end{array}$ & $\begin{array}{l}\text { It concentrates on pitch and the gradual } \\
\text { replacement of normally produced pitches by } \\
\text { natural harmonics - scherzo-like in its nature. }\end{array}$ \\
\hline VII & $\begin{array}{l}\text { 'Short Shadows': evokes the idea of the } \\
\text { Augenblick - the moment of revelation - through } \\
\text { the image of the sun approaching its zenith. }\end{array}$ & $\begin{array}{l}\text { The exploration of the expressive potential of the } \\
\text { instrument in a structure of six sections of six bars } \\
\text { each in which a surrealistically miniaturised time } \\
\text { frames attempts at using every conventional } \\
\text { device of traditional guitar usage. }\end{array}$ \\
\hline
\end{tabular}

I found various degrees of similarity between Benjamin's texts and the score: some of them as proper evidence and others more subjective to interpretation or just more general. I will examine in more

${ }^{34}$ After Benjamin, Selected Writings, pp. 699-702, and Ferneyhough, 'Kurze Schatten II for solo guitar', pp. 139-152. 
detail the similarities I found in the pair of movements 3 and $4,{ }^{35}$ exposing the mimetic dimension of performance that I could interpolate from them.

In the third thought-image of the sequence, 'The Tree and Language', Benjamin suggests the existence of a vast language, beyond speech:

I climbed up an embankment and lay down under a tree. The tree was a poplar or an alder. Why have I not remembered which? Because while I was gazing up into the foliage, following its movements with my eyes, I suddenly found that, within me, language was so gripped by it that momentarily the age-old marriage with the tree was suddenly re-enacted once again in my presence. ${ }^{36}$

In my view, it is in the fact that the speaker of this text does not remember the name of the tree that the similarity with Ferneyhough's correlated piece appears. The third movement consists of a series of 14 bars of different lengths in its first half, which runs in retrograde back to its starting point in the second half. This metric organization alternates a bar of sound or event with a bar of complete silence or else an internal subdivision into tenuto and silence. This relationship is reversed in the retrograde version, so that the bars marked with actual music are now essentially silent and vice versa. In the first half, the sound events dominate - with rest bars reduced to an essentially punctuating function - while in the second half, 'aphoristically brief and disconnected sonic interjections are inserted into disproportionately lengthy fields of silence' ${ }^{37}$ That is, there is a sort of conventional phrasing with short interruptions in the first half, which transforms into its unconventional opposite in the second half.

The upper stave for percussion on the top body of the instrument establishes five degrees of register: from 'dark to light' ${ }^{38}$ which means that the guitarist must obtain those distinctions by tapping on the instrument with the fingertips at different points. Example 3 shows the central point of retrogradation. As we can observe in the percussion stave in bar 15, the physical task of tapping at different points on the instrument in such a rapid micro-figure enhances the functionality of the following long bar of silence as a space for deflection of the physical/psychological energy expended in such a condensed event. The long silences in the second half, in between the now miniaturized/condensed phrases, are intended to deflect the residual energy of the previous event and to prepare the sudden emergence of the next - referred to elsewhere as a 'psychologisation' of the performance $\mathrm{act}^{39}$ - bringing into play Ferneyhough's idea of 'a polyphony, as it were, located almost entirely in the mind (and its physical extensions) of the performer'. ${ }^{40}$ Thus, the similarity can be approached in performance by understanding that the mimicking of the rest bars is not really stillness but the embodiment of the deflection of energy of previous events and expectation/preparation of coming events, somehow evidencing the existence of a 'language' inside the skin of the performer.

\footnotetext{
35 See Castro, 'Brian Ferneyhough's Kurze Schatten II' for a similar approach to movements 1 and 2.

36 Benjamin, Selected Writings, pp. 699-700.

37 Ferneyhough, 'Kurze Schatten II for solo guitar', p. 143.

38 Interview with Ferneyhough, 2013.

39 See Lois Fitch, Brian Ferneyhough (Bristol: Intellect, 2013), p. 88

${ }^{40}$ Ferneyhough, 'Kurze Schatten II for solo guitar', p. 144.
} 
Example 3:

Ferneyhough's Kurze Schatten II, 3rd movement, bars 13-16. The central point of retrogradation is the two $\frac{2}{8}$ bars here.

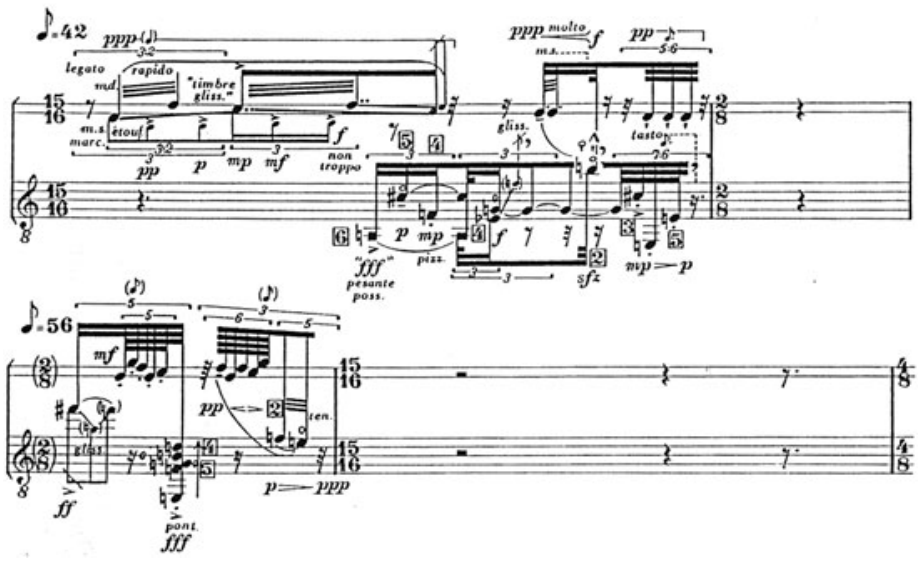

Moreover, in the fourth movement, there is one of the most evident pictorial correspondences between text and score. The fourth thought-image is entitled 'Gambling' and in it Benjamin explores the passion of gambling and describes an image of a real gambler in post-Napoleon Parisian clubs: the Seventh Prince de Ligne ${ }^{41}$ - 'an irreproachable Knight of Fortune' - who was celebrated for the 'cold blood' he displayed in the face of huge losses:

Day in, day out, he behaved in the same way. His right hand, which constantly wagered vast stakes on the tables, hung slackly. His left hand, however, was immobile, held horizontally across his right breast beneath his jacket. Later it became known, through his valet, that there were three scars on his chest the precise imprint of the nails of the three fingers that had lain there so motionlessly. ${ }^{42}$

The three scars on the gambler's chest are paralleled by the strong trace of triplicity in the corresponding piece; the composer regards it as 'a sort of generic waltz, even to the extent of having a clear ABA format and ... the uneven subdivision into 1 beat and 2 beats which a waltz accompaniment typically provides'. ${ }^{43}$ The first section of the piece even remains in ${ }_{8}^{3}$ metre throughout. Ferneyhough states that his most significant pre-compositional decision was to work it out not in terms of individual pitches but in terms of left-hand finger positions; thus, this movement can be seen as a study in left-hand agility seen as an independent variable:

I made a large table of all guitar finger positions ... and all possible combinations of four fingers over any combination of the six strings. I then planned a permutated sequence ..., which I spread out over the entire metric/rhythmic structure of the piece with a view to fixing which combination of strings, placing of fingers and fret position would be available at any given moment. What particularly led me to this approach was the creation of polyphonic continuity while constraining players to realize the notated material in ways which frequently go counter to their instinctive feel for what would be natural. ${ }^{44}$

${ }^{41}$ Charles-Joseph, Prince de Ligne (1735-1814), Belgian military officer, diplomat and man of letters, was a favourite at many European courts. His memoirs and his correspondence with figures such as Rousseau and Voltaire established him as an important literary voice in Belgium.

${ }_{42}$ Benjamin, Selected Writings, p. 700.

${ }^{43}$ Ferneyhough, 'Kurze Schatten II for solo guitar', p. 144. He continues: 'Further operations take this idea much further, by reversing that relationship, changing its proportions (for example into 2 and 3 subdivisions of a $3 / 8$ bar) or by self-replicational "nesting" of such values one within another'.

${ }^{44}$ Ferneyhough, 'Kurze Schatten II for solo guitar', pp. 146-7. 
Example 4:

Ferneyhough's Kurze Schatten II, 4th movement, bars 1-2.
Benjamin's image seems to be the aesthetic motivation for writing a study, based on the notion of triplicity, in which left-hand agility is seen as an independent parameter: it is the same hand that the gambler holds beneath his jacket, auto-imprinting the three scars. The physical demands of notated materials force the performer to use several sound-facilitating gestures, which I decided to emphasize as a structural/expressive element of the performance. These soundfacilitating gestures involve the elbow, whole left arm and trunk in order to facilitate the task of the fingers. Regarding this type of gestures as part of the idiomatic element, its collision with the mensural element becomes an expressive element as noticeable at a physical level. For example, the opening phrase implies a subdivision of one and two beats, in which the two beats are in turn subdivided in three. The opening two chords require not only shifting in between them but also different presentations and the extension of some fingers. The $\mathrm{D}$ harmonic on the second beat requires some stressing plus a small tenuto in order to allow a re-angle of the left arm, as the three following chords (under the 12:7 tuplet) threaten to damp the $\mathrm{D}$ harmonic (besides the fact that each chord requires a different arm presentation). However, it remains very difficult to succeed in not damping the fourth string.

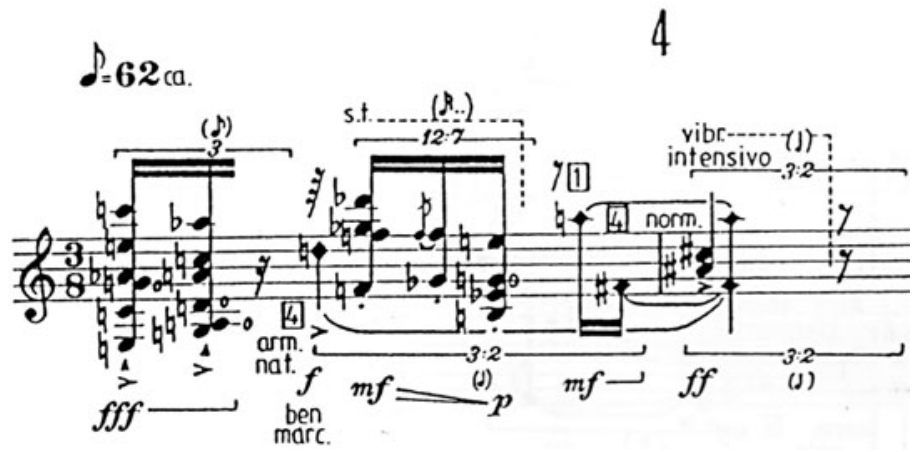

The inherent tension between the idiomatic and mensural elements, the rendition of which produces inevitable mistakes in the realisation, reflects the love for gambling described in Benjamin's text: 'this love contains its own reward, to the point where they [gamblers] even love their losses because this enables them to demonstrate their capacity for self-sacrifice'. This attitude, as the attempt not to compromise the mensural element and to accept failure, can be seen as a correspondence with the text.

In order to explore a waltz trope, sound-producing gestures seem to comply with supporting the main beats in the first section in ${ }_{8}^{3}$, supporting the rhythmic structure, whereas I decided to use 'reverberation' (body motion that continues in the juncture between phrases). ${ }^{45}$ Also, fragmentary melodies often emerge from the chords-pervaded texture, in which many times the convention that accompaniment is softer (and less elaborated) than melody is reversed. Timbral differentiation can help to improve individuation here.

${ }^{45}$ See King, 'Supporting Gestures'. 
Example 5:

Ferneyhough's Kurze Schatten II, 4th movement, bars 20-21.
This feature anticipates the second section (see Example 5), where the two-stave notation reveals a melody/accompaniment relationship stood on its head: the melody, on the bottom stave, is less elaborated and (gesturally) less dense than the upper-stave 'accompaniment'. The distinction is very difficult to achieve in performance, as the dynamics of the melody are mostly lower than those of the accompaniment stave. My approach is to devise an extreme timbral differentiation, which implies playing the bottom stave (melody) more sul tasto (on the sound-hole) - tending more to parallel angles of attack - whereas the accompaniment is played closer to the bridge, tending to more perpendicular angles of attack. Thus, on a physical level, right-hand agility becomes another independent variable, actually mimicking the counter-intuitive behaviour of the left hand - somehow an embodied correspondence with the auto-lacerative image of the gambler's left hand.

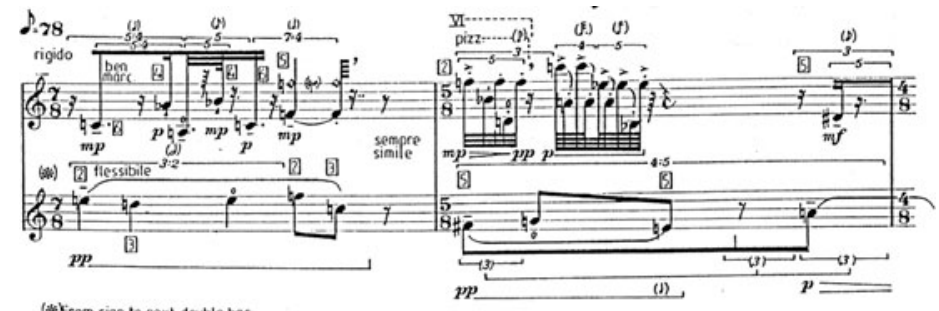

(*) From sign to next double bar lower part vibr; thet hon vibre whenever
note sourding in upper part.

Other similarities on the larger scale within Kurze Schatten II include, in the second movement, the vectorial opposition between tempo and density as a reflection of the dialectical function of money in prostitution in Benjamin's 'A Saying of Casanova's', that it buys pleasure and at the same time it becomes the expression of shame. In the fifth piece, which Ferneyhough describes as a Charakterstück, the topic of 'Distance and Images' approached in Benjamin's text is paralleled in the treatment of chords by different means of articulation, with special emphasis on the lower dynamic reaches. The sixth piece, in turn, explores the transformation of normal sounds into natural harmonics in a sort of scherzo, paralleling the notion of (un)traceability displayed in Benjamin's corresponding text. The seventh movement, however, seems to operate differently.

\section{Benjamin's allegory}

Within Benjamin's sequence, the seventh piece of text, 'Short Shadows', has a double function: it operates both as a single thoughtimage and as the title of the whole sequence - thus, it names each of its preceding texts as a 'short shadow' indeed. Consequently, the task of looking for a text-to-text correspondence seems out of place here.

In Ferneyhough's cycle, the seventh movement - perhaps more than any other - appeals to the so-called fragment-form, through six sections containing six bars each, each bar being made of small gestural fragments. ${ }^{46}$ The composer states that he aims to exploit 'the

\footnotetext{
46 In this way, this movement is prescient of Ferneyhough's Les Froissements d'Ailes de Gabriel, made of 124 fragments which succeed one another.
} 
instrument's expressive potential in a surrealistically miniaturised time frame, and practically every conventional device of traditional usage may be encountered somewhere in this movement in epigrammatic guise' ${ }^{47}$ The use of the fragment-form establishes a connection to the Benjamin quotation from the composer's sketches cited above: 'Ideas are to objects as constellations are to stars'. This derives from Ursprung des Deutschen Trauerspiels (translated into English as The Origin of German Tragic Drama), ${ }^{48}$ the book that drew Ferneyhough's attention in relation to Baroque emblems in the solo piano work LemmaIcon-Epigram. ${ }^{49}$ In the book's 'Epistemo-Critical Prologue', Benjamin approaches the German Baroque Trauerspiel by means of a distantiation between the concepts of the symbolic and the allegorical, as two different means of representation. According to a recent study of Benjamin's concept of allegory, ${ }^{50}$ Benjamin pursues, against the philosophical 'system' that captures truth through an act of symbolic representation, an allegorical method that assembles fragments: which 'juxtaposes the distinct and the disparate', seeking to construct constellations out of the material of the past. The first movement of the allegorical is that of fragmentation - the ruination of contexts of meanings - with the ruin as an emblem of the destructive character of allegory. For Benjamin, the classical trope of such fragmentation is the spatialization in time - temporal meanings are frozen, objects and actions piled up according to structures that are indifferent to their natural meaning. ${ }^{51}$

It could be argued that Ferneyhough's use of the fragment-form corresponds with Benjamin's allegorical method, which also implies a concern with history. According to Benjamin, what distinguishes the allegorical mode of expression from the symbol is its 'strange combination of nature and history': it is the general definition of allegory as the presentation of the meaning of history as nature. Thus, the measure of time for the experience of the allegorical is history and not the 'eternal instant' of the symbol. ${ }^{52}$

The composer states that he aimed to inscribe [his] musical language into the rigorous limits of the historically and physically delimited "text" of the guitar" ${ }^{53}$ - hence the aim of "compacting into a brief space of time as many diverse playing techniques as were compatible with musical coherence. ${ }^{54}$ In 1979 Magnus Andersson, the dedicatee of Kurze Schatten II, asked Ferneyhough to write for the guitar; and they met in 1980 to discuss the physiognomy of the instrument and its clichés, ${ }^{55}$ and it seems that Ferneyhough is confronting these clichés, restored through his own (allegorical) notational means. Allegory, according to Benjamin, is not the conventional representation of some expression, but an expression of convention. ${ }^{56}$ Many guitar clichés in Kurze Schatten II succeed in this, such as the rasgueado

${ }^{47}$ Ferneyhough, 'Kurze Schatten II for solo guitar', p. 150.

48 Walter Benjamin, The Origin of German Tragic Drama, trans. John Osborne (London: Verso, 1998).

49 See Ferneyhough, 'Kurze Schatten II for solo guitar', p. 246.

50 Howard Caygill, 'Walter Benjamin's Concept of Allegory', in The Cambridge Companion to Allegory, ed. Rita Copeland and Peter T. Struck (Cambridge: Cambridge University Press, 2010), p. 248

51 This recalls the 'frozen rhetoric' that Ferneyhough pursues in relation to Lemma-IconEpigram. See Ferneyhough, 'Kurze Schatten II for solo guitar', p. 246.

52 See Alison Ross, Walter Benjamin's Concept of the Image (New York: Routledge, 2015), pp. $56-60$.

53 Ferneyhough, programme note (See fn. 5.)

54 Ferneyhough, 'Kurze Schatten II for solo guitar', p. 139

55 Andersson, 'Brian Ferneyhough: Kurze Schatten II', p. 128

56 See Benjamin, The Origin of German Tragic Drama, p. 175. 
technique in movements 3,5 and 7 - carefully fingered in the flamenco manner - whose appearance of insignificance and indifference in the overall context makes it sound not as a cliché but with an aura of its original context. The more I play this piece in public, the more I receive comments on fragmentary resemblances with sources as diverse as Villa-Lobos and Albéniz, in addition to the Baroque connections.

In conversation with the composer, after rehearsing the piece and because I expressed my interest in Benjamin's texts, Ferneyhough said:

The thing to remember, as with a lot of things with Benjamin, it's history and innovation - everything you do here is really based upon history, but at the wrong speed. And that's why I'm making use of all these suggestions, addressing in some way the configuration of history - in sound, not just the configuration on the fingerboard - and we have to project that into it, that's the auratic quality. ${ }^{57}$

The text-to-text correspondences between these two sequences named Kurze Schatten II challenges the performer to mimic Benjamin's allegory as that 'dialectical exchange between the extremities of nature and history ${ }^{, 58}$ and to re-evaluate conventions in guitar playing, particularly those concerned with the tension as the idiomatic passes through the mensural element - the movement between the extremities of the sonic and the physical. Allegory devalues sensuous form and points beyond itself, requiring one to embrace the nonsensuous similarity beyond musical symbols. Thus, allegorical expression is 'nothing but self-delusion': ${ }^{59}$ meaning does not emanate from the object but from the allegorist. The quotation, 'Ideas are to objects as constellations are to stars', in Ferneyhough's sketches shows the limitation of the image of musical writing, urging us instead to consider its X-ray image.

57 Interview with Ferneyhough, 2013.

58 Ross, Walter Benjamin's Concept of the Image, p. 57.

59 Benjamin, The Origin of German Tragic Drama, p. 233. 